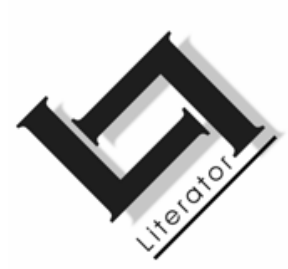

\title{
Crossing lines: the novels of Nadine Gordimer with a particular focus on Occasion for loving and The pickup ${ }^{1}$
}

\author{
Derek A. Barker \\ Department of English (Associate) \\ UNISA \\ E-mail: derek.barker@gmail.com
}

\begin{abstract}
Crossing lines: the novels of Nadine Gordimer with a particular focus on Occasion for loving and The pickup
\end{abstract}

Novelist, playwright, short-story writer, polemicist and activist, Nadine Gordimer (1929), received the Nobel Prize for literature in 1991. She is an implacable opponent of apartheid, which she opposed through her imaginative writing as well as through essays and polemics. The end of apartheid was heralded by the release of Nelson Mandela in 1990, and officially ended with the first democratic elections that were held in April of 1994. Gordimer has produced fourteen novels to date: ten falling clearly within the apartheid period, and four novels that can be classified as falling within the postapartheid period. There is evidence of several general and interrelated shifts in her novels since the demise of apartheid. The previous emphasis on the community and communal responsibility has to some extent been replaced by a relatively greater emphasis on the individual, that is, a move from a stress on public identity to private identity. Local, South African concerns are succeeded by more global concerns. This article discusses these developments, with a specific focus on "Occasion for loving" (1963) and "The pickup" (2001).

1 An abbreviated version of the paper was presented at the Second International IDEA Conference: Studies in English 17-19 April 2007, Hacettepe University, Beytepe Campus, Ankara, Turkey. 


\section{Opsomming}

\section{Oorsteek van grense: die romans van Nadine Gordimer met die fokus op Occasion for loving en The pickup}

Romanskrywer, dramaturg, kortverhaalskrywer, polemikus en aktivis, Nadine Gordimer (1929), ontvang die Nobelprys vir Literatuur in 1991. Sy is 'n onverbiddelike teenstander van apartheid wat sy beveg het deur haar romans, essays en polemieke. Die einde van apartheid is voorafgegaan deur die vrylating van Nelson Mandela in 1990 en amptelik beëindig deur die eerste demokratiese verkiesing in April 1994. Tot nou toe het daar reeds veertien van Gordimer se romans verskyn. Tien van die romans kon duidelik geklassifiseer word as verhale binne die apartheidsera en vier romans as verhale in die postapartheidsera. Daar is bewyse van verskeie algemene en verbandhoudende veranderings in haar romans sedert die einde van apartheid. Voorheen is klem gelê op die gemeenskap en gemeenskaplike verantwoordelikhede. Die klem word egter nou tot 'n mate verskuif na die individu. Tans val die aksent dus eerder op openbare identiteit as op private identiteit. Plaaslike Suid-Afrikaanse aangeleenthede word afgewissel deur meer universele aangeleenthede. Hierdie artikel bespreek hierdie tipe ontwikkelings met die fokus op "Occasion for loving" en "The pickup".

\section{Introduction}

Gordimer has published fourteen novels to date, $\mathbf{2}$ ten during apartheid, and four since its demise in April 1994. Born in 1923, Nadine Gordimer turns 84 this year. Her first book-length publication was a collection of short stories published in 1949 and she has not stopped writing and publishing since - an impressive 58-year record. Her writing includes fiction and non-fiction, short stories and novels, polemics and literary criticism. From the start of her writing career and throughout apartheid, Gordimer's writing and political position has been resoundingly critical of the apartheid regime and against racism in any of its many manifestations, though particularly of course the institutionalised racism that was apartheid.

$2 \quad$ List of novels by Nadine Gordimer: The lying days (1953); $A$ world of strangers (1958); Occasion for loving (1963); The late bourgeois world (1966); A guest of honour (1970); The conservationist (1974); Burger's daughter (1979); July's people (1981); A sport of nature (1987); My son's story (1990); None to accompany me; (1994); The house gun (1998); The pickup (2001); and Get a life (2005). 
It might well be assumed, therefore, that the fall of apartheid bereft this writer of her main target and subject matter. Quite evidently this is not the case. Confounding all such expectations, she has continued to write apace. A corollary assumption might be that the dramatic political changes would be reflected in a dramatic departure or new set of themes in the postapartheid period. Indeed, there are some important shifts, and these will be touched on briefly below. However, it is no easy task to divide her work neatly into apartheid and postapartheid periods, if for no other reason than that each novel has responded very uniquely to issues of the day.

This article begins holistically, placing the fourteen novels in an overall framework, discussing certain shifts in emphases or orientation since the end of apartheid. The subsequent section contrasts one apartheid novel, Occasion for loving, published in 1963, with a postapartheid novel, The pickup, published in 2001. This comparison highlights the general shifts apparent in the entire oeuvre. In addition, seen in their specificity, there are important differences and similarities between these two novels. The conclusion draws the threads of the overall and specific discussions together, highlighting the most pertinent insights gained from the analysis.

\section{Gordimer then and now: apartheid novels versus postapartheid novels}

In a highly illuminating article, Ulrike Augu, discussing public intellectuals, makes a comparison between Nadine Gordimer and the former East-German writer-intellectual Christa Wolf (Augu, 2003). Through borrowing and adaptation of the identity theories of Manuel Castells, she develops the following useful typology of intellectuals: resistance-intellectuals, legitimising-intellectuals and project-intellectuals (Augu, 2003:10-11). Briefly, resistance-intellectuals explain and support devalued or subjugated positions in society; legitimising-intellectuals serve as apologists for dominant institutions in society, extending and rationalising their existence and conduct; project-intellectuals serve to transform society through a creative process of supporting new positions, justifying and rationalising these in turn.

In Augu's view, and I would concur generally with her findings in terms of the novels, Gordimer was very clearly a resistance-intellectual during apartheid. Thereafter, her critique of the political status quo, while not absent, is tangential. Augu views Gordimer's relative quiescence, but also some of her statements, as proof of tacit en- 
dorsement of the postapartheid political regime, in spite of the fact that many of the government's policies do not tally with the socialist views imputed to her. Hence, Augu concludes that the postapartheid Gordimer is a legitimising-intellectual. This appears generally accurate and neatly frames the two periods.

Of course, there is a lot more going on between the covers of a book than simply the support or critique of a regime. This is especially the case in Gordimer's oeuvre. Her books are so multi-faceted that they defy easy categorisation, and justify the multiple attempts and wide variety of approaches applied in trying to achieve just that. Clingman (1981; 1993) offers an influential reading of the novels from a historical-materialist perspective, viewing them as "history from the inside", reflecting and engaging, in theme and form, with the particular historical setting of each novel, paralleling the personal and political trajectories of the author and the country. Ettin (1993) counters this to a certain extent. He presents us with a more synchronic reading, seeing the novels as the unfolding of a single, larger narrative with significant chronological aspects but with a high degree of consistency in certain thematic as well as formal concerns. Head (1994) counters the former readings that emphasise the realist aspects of her work. He presents us with a reading of the novels as engaging with epistemological and, if obliquely, even ontological issues both thematically and in adaptations of form. He concludes that it is possible to read her work as combining a "postmodernist decentring with necessary ideological recentring" (Head, 1994:193). All of these assessments (which are merely a small representative sampling) focus on the apartheidera novels.

Dimitriu $(2003 ; 2006)$ has made the most important contributions to date in comparisons of Gordimer's apartheid and postapartheid work. If there is a consistent theme throughout all of the novels, it is the exploration of the dialectic between the private and the public selves, and the interplay between these two spheres of existence. Dimitriu would appear to reject the view that the postapartheid novels mark a major shift away from politics. In her view, the personal and political are still very much present, although the apartheid novels emphasise the public-political imperatives. She finds that the postapartheid novels, while still exploring the public and private spheres of existence, evince a "more socially diverse, more politically various, and more spiritually inclined landscape of personal possibility" (Dimitriu, 2003:33).

In my own, admittedly reductive, account of the primary differences, the racial and postcolonial problematic constitutes the main thrust of 
the apartheid novels, even those not set in South Africa. However, these issues do not form the primary focus of the postapartheid novels. Evidently, and we must here register a collective sigh of relief, with the demise of apartheid, writers enjoy considerably more freedom. During apartheid, writers were burdened by the existence if not (always) the fact of government censorship. In addition, prescriptive critics increasingly valorised politically engaged writing over what was perceived to be apolitical. But perhaps most importantly, the end of apartheid brought freedom from an existence overdetermined by government policy.

Under apartheid, whatever one's stake (or lack of it) in the system, or views on the issues, the position of neutrality, or even the illusion of neutrality, was impossible, or at least, not possible without being thoroughly deluded. It is perhaps the sustained belligerence against a hard-won complacency among the white middle and upper classes that constitutes the primary contribution of the apartheid novels. It was hard-won since the maintenance of complacency as well as privilege during apartheid quite evidently required the deployment of considerable mental and physical resources. The relentless irony, even scorn, with which she minutely examines the motives of even the best willed among this group, uncovering their sexual and material motives, is unequalled in the country (see inter alia Abrahams, 1960:148, for an appreciation of her skills as well as the registration of the dismay felt at the relentlessness of Gordimer's analyses).

The apartheid novels vary widely even while maintaining a thematic if not formal continuity. The lying days (1953) traces the development of race consciousness of a white girl growing up in a mining town in early apartheid South Africa; A world of strangers (1958) describes race and politics in South Africa through the awakening consciousness of an outsider protagonist; Occasion for loving (1963) examines cross-racial relationships in the context of laws against miscegenation and over-determination of the personal by the political; The late bourgeois world (1966) examines failures of white-led armed resistance against apartheid; A guest of honour (1970) leaves the frame of South Africa for a fictional postcolonial state facing potential ruin in part through its adoption of a neo-colonial model; The conservationist (1974) depicts the impossibility of the colonial dream and the inevitable decolonisation process underway even as it is resisted; Burger's daughter (1979) records the radical white response against apartheid and the journey from the personal to the political through an awakening and deeper understanding of historical and moral imperatives; July's people (1981) projects a 
possible escalation of the struggle against apartheid into civil war and the teasing out, through depiction of reversals, the essentially hegemonic apartheid relations between white and black; $A$ sport of nature (1987) again projects into a future, this time more utopian than in the previous novel, depicting an inevitable birth by blood of the postapartheid state. My son's story (1990), set in the apartheid present of the novel, engages again with political imperatives successfully impinging upon and subsuming sometimes hedonistic personal imperatives, with all the compromises and contradictions this entails. All deal with issues of race relations, apartheid, or in projections of life after the victory over oppression. In Wagner's $(1995: 70)$ view, the apartheid novels

charted the struggle of ... protagonists to shape a viable identity for themselves despite, and because of, the history they are caught up in, and to escape the determining imperatives of the time ...

The four postapartheid novels, while continuing to deal with issues of race and oppression, do not depict political reality as impinging upon the personal in such a determining manner as before. In addition, they widen the purview, situating issues more globally. As Dimitriu (2006:159-160) insightfully argues:

[Gordimer] seems to have renounced her exclusive focus on South Africa which, in the past, she considered to have been 'the example, the epitome of cultural isolation' ... Now that writers feel less moral pressure to engage with a repressive social context, [Gordimer] is keen to offer literary replies to an important question: How, in national specificity, does each country go about moving beyond itself, to procreate a culture that will benefit self and others?

Gordimer's answers to the new challenges are varied and constitute a definitive shift in orientation. None to accompany me (1994) deals with the transition period after the release of Nelson Mandela in 1990 , white and black identity in the new regime, reconstruction of the country, and land restitution. The house gun (1998) again deals with issues of transforming identities in postapartheid South Africa, interestingly engaging with representations of the law and courts, clearly endorsing the new constitution and its values, and presenting a rather unreflecting universal endorsement of the document as the voice of the people (Lenta, 2001). The pickup (2001) delves into the issue of illegal immigration, critiques capitalist exploitation and, to a certain extent if obliquely, tackles Western-Muslim relations. Get a life (2005) primarily foregrounds ecological issues, overtly placing 
these in an international context and within a critique of capital, again - as with all the postapartheid novels - providing an interesting subtext on the law, constitution and human rights.

Hence, we see a move out of the intensely politicised South African frame onto the international stage, or if you will, a globalisation of her writerly concerns. This is not to understate the importance of the personal journeys of individuals in any of the novels, a matter of increased emphasis in the postapartheid narratives. In a sense, and perhaps paradoxically, it is the intense treatment of the private sphere in these novels which redeem them from somewhat flimsy critiques of the above-mentioned "global issues" (the critiques are not substantially developed, though they do serve the purposes of the narratives), and at the same time strengthens these critiques by rendering the personal plights of individual protagonists so compelling. These issues, and the primary differences between the apartheid and postapartheid novels, are clearly revealed in a close reading of Occasion for loving and The pickup. The next section highlights the similarities and differences between these two texts in order to demonstrate the above claims as well as to tease out particularities of the two novels.

\section{Comparison between Occasion for loving and The pickup}

In this section, I present a comparison between Occasion for loving (1983 [1963]) and The pickup (2002 [2001]). An astounding 38 years separates these two novels. However, the involvement of chief protagonists in cross-racial relationships, the straddling by the novels of the apartheid and postapartheid eras, and other similarities and differences, all point to the possibility of a potentially fruitful analysis based on such a comparison. The two novels share the device of the outsider-protagonist, used to throw new, fresh light on what might otherwise go unnoticed. Both novels feature a central, crossracial relationship and thematise love across boundaries. The female halves of the relationships represent the active, steering agents, and the male protagonists the passive, subjugated agents. However, there are some seeming reversals. The lover in the pair who appears to be unselfconscious in respect of racial difference is the outsider to South Africa in Occasion for loving (Occasion), and the insider in The pickup (Pickup). The relationship in Occasion is so over-determined by the local socio-political environment that it appears doomed from the outset and indeed fails in the end. The international socio-political environment in Pickup considerably de- 
termines the relationship between the couple. However, though the relationship might appear doomed, the couple marry and settle, even if at the close of the novel the future remains unclear. Paradoxically, the relationship in Occasion appears to have content beyond the sexual and ultimately is a positive representation of the possibility of cross-cultural alliance and mutual understanding, while the relationship in Pickup leaves the reader ultimately uncertain as to the possibility of bridging such differences.

In Occasion, the foreigner is a white English woman, Ann Davis, who enters a relationship with Gideon Shibalo, a black South African. Ann Davis is oblivious to the local prejudices and does not feel confined as the locals do, either legally or psychologically, to the laws against miscegenation or norms informing cross-racial relations (Gordimer, 1983:27-29, 89). In The pickup we have Julie Summers, a white South African woman who begins a relationship with an illegal immigrant, Ibrahim Ibn Musa (who becomes acquainted with Julie at first using the pseudonym of Abdu). In the latter case, there are no laws against cross-racial relations, and it is the local protagonist who feels free and uninhibited, not the outsider (Gordimer, 2002:7-20).

Occasion sees the cross-racial relationship fail at the end with Ann suddenly taking off with her husband Boaz (Gordimer, 1983:274). In Pickup the relationship is consolidated in marriage, albeit that in the end Ibrahim goes off to America alone while Julie, his wife, remains in an unnamed Muslim country of her own volition (Gordimer, 2002:265-267). The general thesis of Occasion would appear to be that cross-racial or cross-cultural encounters are so fraught under apartheid due to the over-determination of the private sphere by the public sphere that they are bound to fail. In the postapartheid novel, there is no clear thesis.

The relationship in Occasion is comparatively deep, even though the respective couples in both narratives come from diametrically opposed worlds. In both novels, the couples enjoy picnics. In Occasion there is description of vivid repartee, discussions that take place during hours spent alone together on a variety of outings (Gordimer, 1983:133-136). In Pickup, conversation during picnics is sparse. Abdu/lbrahim does not understand words, is not able to join in Julie's reading, and on group outings he ends up in the role of observer/listener (Gordimer, 2002:34-35).

Throughout Occasion, the couple's communication and enjoyment of each other's company outside the bedroom is rich, while in Pickup 
it is distinctly muted if not mute. In neither book do the couples enjoy the privilege of a shared first language. However, in Occasion, this fact is not merely glossed over, but the couple is represented as enjoying virtual intellectual and physical communion. In the bedroom, the initial love scenes are highly reflective of the respective dynamics of each relationship. In Occasion, this event is described as follows:

They began to kiss and please each other with some rivalry, like a pair of peacocks showing off their feathers. If there was laughter, there was also fascination. At last there was solemnity too, but it was the hectic solemnity of surprising passion. (Gordimer, 1983:107.)

This is a rapturous, playful and mutually gratifying experience for both Gideon and Ann, and is clearly reflected in the unfolding relationship that is enriching and enjoyable for both parties. This contrasts starkly with the same event in Pickup:

She approached to take [the towel] from him ... She moved her palms up his arms ... They embraced. ... If they really had desired one another so much it had not evidenced itself before ... they made love beautifully; she so roused and fulfilled that tears came with all that flooded her ... He did not spend the night ... He drove back to the locked and deserted garage ... in the calm and passing content that follows love-making as it does not, he recognizes, what her friends round The Table call a fuck. (Gordimer, 2002:27-28.)

The passage is particularly telling in that it foreshadows what unfolds as a rather asymmetrical relationship: she is roused to tears while, though he is moved more than he would by a mere fuck, his arousal is a "passing content". The scene reflects, too, the active role that Julie plays in initiating all important events in their relationship, from first encounters and dates through to their marriage, and his general passivity, letting the relationship happen rather than playing any decisive role in it.

The male protagonists in both novels are in dire situations that put them at a considerable disadvantage vis-à-vis their female counterparts. This situation may account in general for the active roles played in both relationships by the female protagonists. In Pickup, Ibrahim is an illegal immigrant, desperately hoping to obtain legal entry into an economically prosperous country that would enable him to realise his dreams of education and economic advancement. In Occasion, Gideon's dreams of taking up his scholarship in Italy 
were put paid to by the confiscation of his passport. Although his relationship with Ann appears doomed from the start, a desperate plan is briefly entertained involving illegal exit from the country, with the possibility of being reunited in Tanganyika (Gordimer, 1983:273).

Interestingly, the desperation of the respective situations causes opposing responses in the male protagonists. In Occasion, Gideon would be foolish to fall in love with Ann, a married white women, given his political commitments, the impossibility of legal cohabitation let alone marriage in South Africa, and his very uncertain personal prospects should he take the only path possible, that is, permanent exile. Nevertheless, rather than fighting love, both protagonists grow close, severely complicating the love triangle and very nearly destroying Gideon, who turns to alcohol when the relationship ends (Gordimer, 1983:211, 280-288). In Pickup, by contrast, Abdu/Ibrahim remains cold: his desperation, it appears, is translated into a refusal to allow his feelings towards Julie to grow: "he resists residue feelings of tenderness towards this girl", and refuses to translate "love words" into his own language for Julie (Gordimer, 2002:28, 152). Latent feelings do, nevertheless, appear to force their way to the surface of Ibrahim's consciousness:

\begin{abstract}
... she had come ... all the way with him ... love. He had to believe it, existing in her. He felt something unwanted, something it was not necessary, no obligation on a penniless illegal to feel for one of those who own the world, can buy a ticket, get on a plane, present a passport and be welcomed back into that world any time ... he felt responsibility - that's it - responsibility for her. Though he had none: he had not wanted her to come here ... (Gordimer, 2002:173-174).
\end{abstract}

The one possibility in his own country, to take over the garage of his uncle and which would ensure him a livelihood, even if not the one desired, is refused (Gordimer, 2002:191-194) - this should be recalled before assuming any necessary link between his lack of feeling and the degree of desperation. In a general discussion, the main thrust of which is a critique of Islam and calls for modernisation, one of Ibrahim's friends states (Gordimer, 2002:177):

I just read it somewhere. 'A Muslim doesn't fall in love with a woman, but only with Allah,' - He kept a gloomy face, perhaps himself a lover in difficulties, while there was more laughter the others evidently did not regard the cynicism as blasphemous. 
The most straightforward way to account for Ibrahim's lack of feeling towards Julie is to simply impute it to a strength of will or determination, itself an index of the depth of his desperation to escape his circumstances: to fall in love would scupper his plans to rise in the world, at least in his view. This appears the most plausible reading. After all, in spite of the reported quotation above, the drift of the narrative in no way suggests that it is on account of Ibrahim's religion that he withholds his love from Julie. If this holds true, then this refusal to love is on account of a personal trait of the protagonist, and not imputable simply to straitened circumstances.

However, due to the threadbare characterisation of Ibrahim, it appears faintly possible that he is being presented as a type, in terms of the Lukácsian notion of character in the critical realist novel being both a representation of individuality and typicality (Lukács, 1978). As a type, the representation of Ibrahim would take on general (public) as opposed to specific (private) applicability. If the character of Ibrahim functions as a type rather than as an individual, the suggestion here would seem to be that, as a general rule, desperation makes love impossible, and the appropriate response in the reader should be indignation at the dehumanisation that poverty causes, and the corresponding need to address the plights of those oppressed in a similar manner. If so then why, in spite of different but nevertheless similar extremity of circumstance, is it possible for Gideon, a "Christian" black South African, to fall in love, but not possible for Ibrahim, a "Muslim"? What is the crucial element of difference that would set the plights of the two men at odds? I will return to this issue in a discussion of the treatment of alterity in the novels further below.

In addition to the question of love, the perspectives of Ibrahim and Julie on their own relationship are so different that, while this makes for wonderful and rich irony throughout the novel, one is left wondering what common ground they could possibly share and what basis exists for their relationship. It would seem to be purely sexual. Cloete (2005:61) insightfully notes that "it is only in their sexual union that they find perfect fulfilment". The text is filled with allusions to the couple's near total lack of mutual understanding. Apart from the perfection of their union on the sexual level, there seems almost nothing shared. She is from a rich, white family in a developing if not developed country, he is from an undisclosed but clearly Muslim, undemocratic, poor and underdeveloped country: a "benighted" place which is "hell" riddled with "religious and political factions", "corrupt" and mostly desert (Gordimer, 2002:14, 109, 131). She wishes to es- 
cape her privileges, he wishes to have her privileges. Failure of the relationship seems predestined. The novel ends rather surprisingly with Ibrahim's dream of going to America fulfilled when, through her money and contacts, he obtains a work-permit. With two tickets in hand, he prepares for their journey to America - the land of promise for him, the land of her mother and everything she despises for her. To his utter astonishment, he is confronted with her astounding decision to stay behind in the country he detests but which she has grown to love (Gordimer, 2002:260-268). Again, unlike Gideon in Occasion, whose response to the departure of Ann is near self-annihilation, Ibrahim's response is cold while his family is emotionally effusive, and he leaves without looking back once (Gordimer, 2002:267). The two male protagonists in the novels could not be more different.

The treatment or representation of the "Other" or alterity, from whichever viewpoint, differs interestingly, and perhaps disturbingly, in a comparison between the two novels. The differences in skin colour, speech, habits or ways of seeing things are never avoided or glossed over in any Gordimer novel. Rather, difference is displayed though never fetishised. In Occasion, Ann appreciates the look of black bodies and Jessica, coming across the sleeping couple, is portrayed as appreciating Gideon's "dark body" and the "shine going down the curve that followed the groove of the spine to the short, gleaming roundness of the buttocks," (Gordimer, 1983:250). The racial origins of "Julie's find", Ibrahim, is initially a source of confusion for both her and her friends who were not able to categorise him and his origins on the basis of his darker skin tone and black hair (Gordimer, 2002:7, 10, 30). Hence, Gordimer's representation of difference is generally appreciative.

Taking all the foregoing into consideration, though, one might yet be excused for wondering whether the implacable alterity between the Western and Muslim worlds - an implicit assumption of irreducible difference - might not be informing the structure of this relationship in Pickup. In Occasion, something extrinsic, the apartheid laws and social norms that the lovers don't accept, impinge upon them from outside, ultimately rendering their relationship impossible. In Pickup, something intrinsic, something flawed perhaps, inside the very cocktail of Western female in relationship with the Muslim male, might well be the crucial difference that renders the relationship impossible. Since there is nothing in law or in modern convention preventing the relationship, they are married and live together. Yet, though 
physically sharing the same space, psychologically they are worlds apart.

Another conundrum is the enigmatic ending. Julie clearly finds sexual fulfilment in the relationship, and this seems to be the larger part of its success, driven as it seems primarily by her and motivated by her desires, as Ibrahim's desires appear to be directed outside the relationship and in his future career. All the same, it appears plausible to suggest that part of what Julie sees in Ibrahim is his representation, for her, of everything her life and her family is not, that is, as an opposite or pure alterity, attractive because of the very high degree of repulsion against what she feels she stands for. The irony of course is that it is exactly what she rejects that he wants. An additional source of irony is that, even if Julie's rebellion against the values and lifestyle of her parents led her to settle for a relatively ascetic existence in the first part of the novel, she nevertheless lives a lesser version of the despised bourgeois lifestyle of the parents.

When she meets Ibrahim, the life she lives is far from uncomfortable: although quartered in an outhouse converted into a cottage in someone's backyard, she has hot water, bathroom, fully equipped kitchen, and all the usual material comforts even if only in modest form (Gordimer, 2002:18). These comforts are noted and appreciated by Ibrahim, particularly the hot water and bathroom. She enjoys a steady income and the concomitant independence that such a status grants her, as well as sufficient leisure time for friends and fun. Would she give up both this and the husband, who at the end leaves her for America indefinitely, in exchange for a lonely life in a lean-to on the edge of a desert in an obviously very poor country? On his departure, she is depicted, by Ibrahim, as truly bereft of all that matters to her as he muses (while overtly withholding parting comfort):

Let her have an idea of what she doesn't realise ... this place in the desert, without him, without the love-making she needs so much, without anyone to talk to who, as he does, knows her world, without - yes, he can admit it to himself only, without his love for her. That weakness that is not for him. She could not approach him. He held her off by his right ... (Gordimer, 2002:266).

Not only is she losing him, but also as he sardonically muses, she loses the last vestige of her formally privileged existence. She is out of place in the desert, without her hot running water, in a lean-to, in the company of mostly hostile or indifferent women (with whom she, 
nevertheless, has formed incipient bonds towards the end of the novel). Why does she do it? It is difficult not to concur with Ibrahim's explanation for her decision to stay on: "... her decision was a typical piece of sheltered middle-class Western romanticism," (Gordimer, 2002:262). However, though this appears roughly accurate, there may be more to it than this.

Although her ability to communicate with members of the community is rudimentary - the only clearly positive relationship she has is with Maryam - no men interact with her and all other women keep her at arm's length - her possible place in the society is potentially selfaffirming. The community's apparent need for an English teacher possibly provides her with a sufficient sense of purpose that, while it may not translate into full social acceptance, may yet suffice.

In spite of the fact that both protagonists are treated to what almost amounts at times to authorial mockery and, for the reader, delightful irony, their dreams and individuality are yet not dismissed. Their reasoning might be muddled and ill-understood even by themselves, but the hard choices they make have enormous personal consequences, and can therefore not be dismissed lightly. One might not understand the protagonists, but one comes to appreciate (if not endorse) the rich girl's self-defeating rebellion and the dreams of the struggling outsider. Their predicaments are belittling, but the decisions are never belittled.

Perhaps, therefore, the protagonists and the ending are more credible than one at first perceives. Julie is a complex and complicated character, strong-willed and flippant. While her decision to stay on constitutes more than a mere "adventure" (as all her decisions are presented in the novel), it may be rather more far fetching than farfetched. Although the fact that her family's wealth renders it possible for her, unlike any of the members of the community she joins, to return to a life of relative luxury, the decision to stay on appears to be a deeply felt and existential one. The decision seemingly feels right to her without it necessarily being clear to either her or the reader why it feels right. Dimitriu (2003:32) reads this decision as empowering:

... she embarks on a journey of self-discovery that proves to have no boundaries other than those imposed upon her by her own inner dedication. Rejecting what she comes to regard as the superficial landscapes of global opportunities, she identifies the map of her own inner life as a new country of exploration. 
Therefore, if doubts are still entertained, suspending disbelief here seems warranted. There appears some likelihood that Julie's decision is not merely impulsive or ephemeral, that she means to stay on for good, a daunting prospect and brave decision, in full knowledge of the circumstances, having already survived a year in the country. In this sense it is life affirming, self-empowering even while it is, to a certain degree, self-effacing.

\section{Conclusion}

Published in 2001, Pickup was not written after 9/11, and the Western/Muslim theme was not yet as topical, or as fraught, as it is today. Gordimer's exploration of the two characters from diametrically opposed worlds may simply be a device to shed light, to help us see "anew" a variety of issues inter alia the responsibility of the rich and well-off and the dire plight of the so-called economic refugees, no small or slight matter in today's world. As already indicated, the device of the outsider-protagonist towards such ends is not a new narrative strategy in Gordimer's oeuvre. Nevertheless, paradoxically, it does appear that the failed relationship in Occasion is ultimately the more positive representation of the possibility of cross-cultural alliance and mutual understanding than the successful relationship in Pickup.

The foregoing close reading of Occasion and Pickup has hopefully produced insights of a specific nature to each text. In addition, in comparing the novels, the shifts identified in Gordimer's apartheid and postapartheid novels are evident. The critique of the political status quo in Occasion is overt, and in line with Augu's understanding of the Resistance-Intellectual position, while the tangential treatment of politics in Pickup in more in line with the Legitimisingintellectual role. The thematising of the dialectic between the private and the public selves is foregrounded in Occasion while Pickup deals only indirectly with this problematic. In addition, the overt theme of racial difference that we see in Occasion, though very much present, is relatively secondary in Pickup.

The evidence of individuals oppressed by external forces is everywhere evident in Occasion whereas individual agency and responsibility for one's own plight is certainly stressed in Pickup. In the later novel, the protagonists are never depicted as inescapably bound by circumstance, and their predicaments are mainly the result of personal desires and decisions. While Abdu/lbrahim is poor, and this leads to desperate actions, at no point is poverty alone blamed for any decisions he makes. And lastly, Occasion deals with "South 
African issues" while "global issues" come into focus in Pickup. These shifts, I have argued above, are evident in a comparison between Gordimer's apartheid and postapartheid novels. The two novels merely throw into sharper relief the key points of difference, and such an exercise arguably provides a helpful framework within which to better understand her oeuvre.

Turning to specific differences between the two novels, however, the most striking insight flowing from the analysis above is the fact that, in Occasion, there is evident optimism about the possibility of crossracial or cross-cultural relationships, while we find a striking pessimism about the possibility of bridging alterity in Pickup. That this is the case appears fairly certain. Why this is the case, is far from clear. I would tentatively suggest that Gordimer here faces, together with much of the Christian world, the limits of the liberal-humanist ethos of tolerance and (previously) unshakable belief in the universal community of mankind. The message of the novel, it appears, is that certain differences are ultimately unbridgeable.

\section{List of references}

ABRAHAMS, L. 1960. Nadine Gordimer: the transparent ego. English studies in Africa, 3(2):146-151.

AUGA, U. 2003. Intellectuals between resistance and legitimisation: the cases of Nadine Gordimer and Christa Wolf. Current writing, 15(1):1-16.

CLINGMAN, S. 1981. History from the inside: the novels of Nadine Gordimer. Journal of Southern African studies, 7(2):165-193.

CLINGMAN, S. 1993 [1986]. The novels of Nadine Gordimer: history from the inside. London: Bloomsbury.

CLOETE, M.J. 2005. A study of identity in post-apartheid South African English literature: The pickup by Nadine Gordimer. Literator, 26(1):49-67.

DIMITRIU, I. 2003. The end of history: reading Gordimer's post-apartheid novels. Current writing, 15(1):17-37.

DIMITRIU, I. 2006. Postcolonialising Gordimer: the ethics of "Beyond" and signficant peripheries in the recent fiction. English in Africa, 33(2):159-180.

ETTIN, A.V. 1993. Betrayals of the body politic: the literary commitments of Nadine Gordimer. Charlottesville: University Press of Virginia.

GORDIMER, N. 1971 [1970]. A guest of honour. Cape Town: Jonathan Cape.

GORDIMER, N. 1976 [1958]. A world of strangers. Cape Town: Jonathan Cape.

GORDIMER, N. 1978 [1953]. The lying days. Cape Town: Jonathan Cape.

GORDIMER, N. 1978 [1974]. The conservationist. London: Penguin.

GORDIMER, N. 1980 [1979]. Burger's daughter. London: Penguin.

GORDIMER, N. 1982 [1966]. The late bourgeois world. London: Penguin.

GORDIMER, N. 1983 [1963]. Occasion for loving. London: Virago.

GORDIMER, N. 1987. A sport of nature. New York: Knopf.

GORDIMER, N. 1992 [1981]. July's people. New York: Quality Paperback Book Club. 
GORDIMER, N. 1992 [1990]. My son's story. New York: Quality Paperback Book Club.

GORDIMER, N. 1995 [1994]. None to accompany me. London: Penguin.

GORDIMER, N. 1999 [1998]. The house gun. London: Bloomsbury.

GORDIMER, N. 2002 [2001]. The pickup. London: Penguin.

GORDIMER, N. 2006 [2005]. Get a life. London: Bloomsbury.

HEAD, D. 1994. Nadine Gordimer. Cambridge: Cambridge University Press.

LENTA, P. 2001. Executing the death sentence: law and justice in Alan Paton's Cry, the beloved country and Nadine Gordimer's The house gun. Current writing, 13(1):49-69.

LUKÁCS, G. 1978. Writer and critic. Trans. Arthur Kahn. London: Merlin.

WAGNER, K. 1995. The enigma of arrival: Nadine Gordimer and the politics of identity in None to accompany me. English academy review, 12:70-83.

\section{Key concepts:}

apartheid and postapartheid: South African English literature Gordimer, Nadine: Occasion for loving

Gordimer, Nadine: The pickup

identity

\section{Kernbegrippe:}

apartheid en postapartheid: Suid-Afrikaanse-Engelse literatuur Gordimer, Nadine: Occasion for loving

Gordimer, Nadine: The pickup

identiteit 
